\title{
Meeting Announcements
}

Notices of relevant future meetings are published free of charge. Copy for publication must, however, be with the Publishers at least 8 weeks before the beginning of the month of publication of the relevant issue of the journal.

\section{5}

\section{0-24 May}

5 th Joint Congress of the

Sexually Transmitted Diseases

and Infectious Diseases

Societies of Southern Africa,

Durban, South Africa,

Contact: Dr A.A. Hoosen,

Department of Medical Microbiology,

University of Natal, PO Box 17039,

Congella 4013, Durban, South Africa.

Tel: $(+27) 313603195$

Fax: $(+27) 312604431$

\section{5-26 May}

Biological Safety,

Bethesda, MD, USA.

Contact: Mr Ben Keddy,

Cambridge Healthtech Institute,

1000 Winter Street,

Suite 3700 Waltham MA 02154, USA.

Tel: (+ 1) (617) 4877989

Fax: $(+1)(617) 4877937$.

\section{6-21 July}

19th International Congress of

Chemotherapy

Montréal, Québec, Canada.

Conlact: I9 ICC Secretariat,

205 Viger Avenue West,

Suite 207, Montréal, Québec, Canada.

Tel: ( + 1) (514) 871-1995

Fax: $(+1)(514) 871-2870$.

\section{0-22 July}

Federation of European

Microbiological Societies FEMS:

Symposium on Recent Advances

in the Diagnosis of Viral Diseases,

Istanbul, Turkey.

Contact: Osman Sadi Yenen, MD,

Department of Infectious Diseases,

Gülhane Military Medical Academy

Haydarpasa Teaching Hospital,

81327 Haydarpaşa, Istanbul, Turkey,

Tel: $(+90) 2163472416$

Fax: ( + 90) 2122304409 .

\section{6-12 August}

Tenth International Conference on

Global Impacts of Applied

Microbiology and Biotechnology:

GIAM X, Copenhagen, Denmark.

Contact: GIAM,

University of Copenhagen,

Dept of General Microbiology,

Sølvgade $83 \mathrm{H}$,

DK-1307 Copenhagen K,

Denmark.

Fax: (+45) 35322040 .

\section{August-1 September}

17th International Specialized Symposium on Yeasts, Yeast Growth and

Differentiation

Edinburgh, Scotland.

Contact: Dr Colin Slaughter,

Department of Biological Sciences,

Heriot-Watt University,

Riccarton, Edinburgh EH14 4AS, Scotland

Fax: (+ 44) (031) 4513009

\section{4-29 September}

Australian Society for Microbiology

Scientific Meeting and Exhibition:

Microbes in the ACT.

Canberra, Australia.

Contact: ASM 95 Secretariat,

GPO Box 128,

Sydney NSW 2001, Australia.

Fax: (+61) 22622323.

\section{2-6 October}

XII International Symposium on

Problems of Listeriosis

Perth, Western Australia.

Contact: Promaco Conventions Pty Ltd,

ACN 008784 585, Unit 9A,

Canning Bridge Commercial Centre, 890-892 Canning Highway Applecross,

Western Australia 6153. Fax: $(+61)(9)$ 3161453.

\section{6}

12-16 August

Ioth International Congress of Virology

Jerusalem, Israel

Contact: Secretariat: IUMS Congresses

1996

PO Box 50006,

Tel Aviv 61500, Israel. Tel: $(+972) 3$

5140014

Fax: (+972) 35175674.

\section{9-23 August}

8th International Congress of Bacteriology and Applied Microbiology (BAM) and

Mycology,

Jerusalem, lsrael.

Contact: Secretariat: IUMS Congresses 1996,

PO Box 50006, Tel Aviv 61500, Israel.

Tel: (+ 972) 3 5175674/660325.

\section{5-30 August}

10th International Biotechnology

Symposium,

Sydney, Australia.

Contact: Australian Biotechnology

Association, P Box 4, Gardenvale Victoria

3185, Australia.

Tel: $(+61) 35968879$

Fax: $(+61) 35968874$.

\section{6-20 September}

Workshop on Structure, Biochemistry

and Molecular Biology of Microbial

Slayers,

Rothenburg ob der Tauber,

Germany.

Contact: Helmut König,

Abteilung Angewandte Mikrobiologie

und Mykologie, Universität Ulm

D-89069, Germany.

Tel: $(+49)(0) 7315022707$

Fax: $(+49)(0) 7315022719$.

\section{Erratum}

In World Joumal of Microbiology \& Biotechnology Volume 10, Number 6 (1994), the first-named author of the paper "Saccharification of indigenous starches by $\beta$-amylase of Bacillus megaterium" (pp. 691-693) was incorrectly cited. The correct names of the authors are Rina Rani Ray, Subhas Chandra Jana and Geeta Nanda. The Publishers and Editors would like to apologize for any inconvenience that the incorrect citing may have caused. 